Goldstein tells the story of the Bund from the street level up. As a union organizer, he often worked with the toughest segments of the Warsaw Jewish proletariat, including slaughterhouse workers and porters. As an organizer, and as head of the Bundist party militia, he also came into contact with members of the underworld and underclass, who often overlapped with his official constituency. As Sherer notes, Goldstein does not deal with ideology or (much) with party congresses. Of course, the Bund never had the chance to institute the kind of socialist society it dreamed of. Even so, as Goldstein conveys vividly, the Bund improved the lives of its members and constituency on an everyday basis. It won occasional material improvements for the workers, and it defended all Jews against antiSemitic attacks. It also raised its members' cultural and intellectual horizons, providing them with the tools to understand their world and their predicament. To its members the Bund provided a close comradely community, with a family feeling that had always been the Bund's hallmark.

Goldstein conveys the difficult conditions of Jewish working-class life in Poland between the wars. He describes the poverty, the anti-Semitism - which ranged from efforts to force Jewish workers out of the slaughterhouses to the institution of "ghetto benches" in the universities - and the political repression. The Bund militia busily battled anti-Semitic hooligans and, occasionally, the police. It was also constantly at war with the communists, who for much of the period under discussion regarded the Bundists as "social fascists" in accord with Comintern policy, and once even launched an armed attack on the Medem Sanitarium. It might surprise some how often gunfire is mentioned in a memoir of interwar Jewish life. Significantly, Goldstein also frequently notes cooperation with the Polish Socialist Party, especially when it came to battling anti-Semitism. The Bund's ability to reach out to Polish comrades, even when relations between the parties were sometimes tense at the top, was one of its chief appeals during its election victories. Other Jewish parties simply did not have that connection to counterparts in the majority population. On the other hand, the Bund's relations with the Zionists were hostile, but do not seem to have erupted into violence.

Zuckerman provides a fluid and, for the most part, accurate translation of the original, as well as good notes and a glossary explaining unfamiliar terms, and identifying individuals and organizations mentioned in the text. Twenty Years in the Jewish Labor Bund is published as a "Shofar Supplement in Jewish Studies", and it would make good reading for students of East European Jewish history, modern Jewish politics, or the history of socialist movements, or, indeed, for anyone else without access to the original.

\author{
Daniel Soyer \\ Fordham University \\ History Department \\ 44I East Fordham Road \\ Bronx, NY 10458 , USA \\ E-mail: soyer@fordham.edu \\ doi:10.1017/S0020859017000530
}

The Soviet Gulag. Evidence, Interpretation, and Comparison. Ed. by Michael David-Fox. [Pitt Series in Russian and East European Studies.] University of Pittsburgh Press, Pittsburgh (PA) 2016. xi, 434 pp. ill. \$49.95. 
Since researchers started to gain access to the long-closed archives during the "archival revolution" almost three decades ago, studies of the Soviet camp system have thrived. The controversies and debates that emerged after these archival discoveries made Gulag studies one of the most dynamic subfields of Soviet history. As Oleg Khlevniuk notes in the present volume, we are "approaching the point at which we merely begin to reproduce or touch up a well-illustrated picture" (p. 25). Research on the individual camp complexes, studies of the legal framework of the installation of the camp system and its changes over time, and statistical surveys of the number of victims and survivors - these are just some of the most active directions of the investigations of recent decades - prepared ground for the further specialization of research and opened possibilities for comparisons that go beyond the traditional focus on the Soviet and Nazi camps. Some of this intriguing new research is presented in this volume. The broad and ambitious project of this book embraces a productive coexistence of a variety of approaches, geographical contexts, and theoretical frameworks.

This multidisciplinary volume contains fifteen chapters, most of which are based on profound archival research and demonstrate the cutting-edge historical and sociological scholarship on the Gulag and penal system in Russia, as well as on research on labour camps in other historical contexts. The bulk of the chapters are written by authors who participated in a 2013 conference at Georgetown University and who published their contributions in a $20 \mathrm{I} 5$ issue of Kritika ${ }^{\mathrm{I}}$ However, for this volume the editor significantly increased the number of contributions and reinforced the comparative perspective. The contributions can be roughly divided into three sections: the first section offers a broader picture of the Soviet repressive system, then several chapters explore specific aspects of the Gulag, while the final part of the volume showcases the research that could serve as a starting point for a comparative reflection.

This volume would be valuable not only for researchers of the Gulag, but also for scholars with a general interest in the history of political repression and modern penal systems, as well as those with a wider academic interest in Soviet history. The main contribution of this book to the historiography is its promotion of a whole range of new perspectives on the role and function of the Gulag in the Soviet Union, thus also enriching the general field of the study of labour camps and other forms of incarceration and forced labour.

The main topic running through this volume is that of relations between the Gulag and Soviet society at large. In his editorial introduction, Michael David-Fox convincingly argues for the need to overcome the persistent metaphor of the camps as an isolated "archipelago" and systematically research the circulations and bilateral breaches of the camp boundaries. This innovative approach allows, on the one hand, Gulag studies to be reconnected with the wider field of Russian history and, on the other, to look beyond the specific carceral facilities and explore the social and cultural consequences of the existence of the Gulag in a longer chronological perspective.

Another merit of the book resides in the fact that the editor strove to take into account the multiplicity of the punitive arrangements in the Soviet Union as well as the diversity of the camp experience for the survivors with different social backgrounds. In this volume, the camps are analysed alongside the "special settlements" (the destinations of the peasant deportations in the I930s and I940s) and "sharashkas" (the secret research facilities for incarcerated scientists). The terrifying and unsettling consequences of the Gulag for the 
millions of people - beyond those who were incarcerated in the camps - unfold before the reader particularly clearly in the contributions of Emilia Koustova and Asif Siddiqi. The former seeks to trace the destinies of the deportees and the repercussions the deportation had on their lives, while the latter looks into how these closed research facilities functioned and what kind of consequences their existence had for the Soviet scientific culture.

This collection also makes an important step towards inscribing the history of the Gulag into global history. The concept of modernity, long present in discussions of Soviet history, ${ }^{2}$ demonstrates its integrative force in these essays as well. Some historical moments and conditions are of particular interest. World War I has long been identified as the first common European experience of pervasive militarization, unprecedented violence, and mass incarceration. In the present volume, Dietrich Beyrau discusses the importance of this camp experience for the construction of the camp systems that followed. Another stimulating analysis is proposed by Aidan Forth, who examines the creation of labour and concentration camps as instruments of the modern "gardening state" in nineteenth- and early-twentieth-century Britain. In an equally compelling contribution, Klaus Mühlhahn looks into the context of the emergence of the labour camp system in China during the I950s and delves into the connections and ruptures between the Chinese and Soviet cases. Overall, the second part of the volume discusses an outstandingly rich array of questions and opens up many paths for future research.

Despite the fact that the volume largely succeeds in the ambitious enterprise of providing the reader with state-of-the-art multidisciplinary research on the Gulag, some critical remarks are also warranted. First, the framework of this book is largely defined by a critical reading of Solzhenitsyn's body of work. This engagement with Solzhenitsyn's view of the Gulag was clearly stimulating: the editor and the contributors consistently confront the metaphor of a bounded, impenetrable "Gulag Archipelago" with their analyses based on the rich archival sources and oral histories, thus producing a more nuanced history of the heterogeneous and complex institution that was the Gulag. However, even such critical reliance on Solzhenitsyn's writings is still problematic. The discussion of the "Gulag Archipelago" is overwhelmingly present throughout the book, while other major authors, such as Varlam Shalamov or Yevgenia Ginzburg, not to speak of lesser-known writers, are mentioned only in passing. It thus sometimes feels as if the plurality of the voices and the perspectives of camp survivors is at risk of being erased.

Second, certain major topics are virtually absent. The two most salient examples are gender and the case of the perpetrators. The only contribution with a gendered perspective is that of Judith Pallot. She analyses the connections between the Gulag and the present-day penal system, but also discusses the prison experiences of women. She engages the most consistently with the larger sociological literature on incarceration, while the majority of the contributors remain wary of social theory. As for the research on perpetrators, it is a wellestablished part of the literature on the Nazi concentration camps and an emerging trend within Gulag studies. Who were the guards and the camp bosses? How did they contribute to the porosity of the borders of the Gulag? A contribution seeking to answer these or similar questions would have given an even fuller understanding of the social history of the Gulag. Similarly, in his introduction the editor states that "the blurred boundaries between free and unfree labour" are discussed in the book, but labour is examined only sporadically.

2. Michael David-Fox, "Multiple Modernities vs. Neo-Traditionalism: On Recent Debates in Russian and Soviet History”, Jahrbücher für Geschichte Osteuropas, 4 (2006), pp. 535-555. 
The consequences of the existence of the Gulag for the non-incarcerated labourers, for instance, are also barely mentioned. Wilson Bell masterfully analyses the mobilization of free and unfree labour, but unfortunately he does so only for one short, albeit crucial, period of the Gulag's existence: wartime.

Another missed opportunity concerns the necessity of a more consistent comparative perspective. The contributors have an outstanding mastery of the existing historiography of the Gulag, but the overwhelming majority of those working on the Soviet case remain largely within the boundaries of the subfield. They engage only marginally with the more general research on the history of camps or history of punishment. By looking beyond the Soviet case and deepening our understanding of the historiography that explores labour and concentration camps in other contexts, future research will benefit considerably.

The innovative and deeply researched essays collected in this book interact in a synergetic fashion and provide the reader not only with insights into the history of the Gulag, but also a rich survey of the social history of the twentieth century. The volume makes it clear that in order to truly understand the Gulag, we need to look beyond it. It also indicates the directions of further developments of Gulag studies: the need to integrate new analytical and theoretical perspectives, continued work on definitions, as well as more consistent comparative analysis.

\section{Zhanna Popova}

International Institute of Social History PO Box 2169, 1000 CD Amsterdam, The Netherlands E-mail: zhannapop@gmail.com doi:10.1017/So020859017000542 